\title{
Jak wspomagać rozwój językowy dzieci wielojęzycznych? Postępowanie logopedyczne w nauczaniu języka polskiego jako obcego
}

How to support bilingual children's language development? Speech therapy in the process of teaching polish as a foreign language

Słowa kluczowe: logopedia, glottodydaktyka polonistyczna, dwujęzyczność, wielojęzyczność

Keywords: speech and language therapy, glottodidactics, Polish as a second language, bilingualism, multilingualism

\section{Wprowadzenie}

Wyjątkowe w ostatnich czasach przyspieszenie procesów globalizacyjnych, które dotyczą nie tylko gospodarki, ale także kultury, wpływa bezpośrednio na nasze życie. Nieograniczone możliwości przemieszczania się i komunikowania z innymi sprawiają, że żyjemy w wielokulturowej rzeczywistości. Dwu- i wielojęzyczność staje się zjawiskiem powszechnym, a nieznajomość języków obcych znacznie utrudnia funkcjonowanie w dzisiejszym świecie.

Wielokulturowość jest wyzwaniem edukacyjnym i wychowawczym. Obecność w przedszkolach i szkołach dzieci wielojęzycznych wymaga podjęcia działań umożliwiających im lepsze funkcjonowanie w nowym środowisku: stworzenia odpowiednich warunków do nauki języka polskiego jako obcego oraz przeciwdziałania izolacji dzieci wielojęzycznych w grupie rówieśników przez włączanie ich do pracy zespołowej. Punktem odniesienia są tu zalecenia Rady Europy, przedstawione w Europejskim

\footnotetext{
* Niepubliczne Dwujęzyczne Przedszkole Kids \& Co., Łódź, ul. Pomorska 106A, 93-521 Łódź, e-mail: magda.bielawska@kids-co.pl.
} 
systemie opisu kształcenia językowego: uczenie się, nauczanie, ocenianie, promujące koncepcję różnojęzyczności ${ }^{1}$, uznając, że:

[...] jedynie dobra znajomość nowożytnych języków europejskich [...] może ułatwić komunikację i kontakty między ludźmi mówiącymi różnymi językami, a tym samym [...] poszerzyć zakres ich wzajemnego zrozumienia i współpracy, jak również przezwyciężyć przejawy uprzedzeń i dyskryminacji [Coste, North, Sheils, Trim, 2003, s. 14].

Autorzy tego dokumentu za ważne uznali rozwijanie sprawności praktycznego posługiwania się językami obcymi, najistotniejsze jest zatem kształcenie językowych kompetencji komunikacyjnych ${ }^{2}$, które "przejawiają się w działaniach językowych, czyli rozumieniu i tworzeniu tekstów (pisanych i/lub mówionych) [...] i w działaniach interakcyjnych i mediacyjnych" [Coste, North, Sheils, Trim, 2003, s. 24].

Wiele placówek oświatowych proponuje więc naukę języków obcych już od najwcześniejszego etapu kształcenia. Ideę edukacji dwujęzycznej oferuje także Niepubliczne Dwujęzyczne Przedszkole Kids \& Co. Jest to przedszkole przyzakładowe, do którego uczęszczają wyłącznie dzieci pracowników firmy Infosys - osób z różnych stron świata, nie tylko z Polski, posługujących się językiem angielskim w stopniu co najmniej komunikacyjnym.

\section{Dwu- i wielojęzyczność}

Według Słownika języka polskiego pod redakcją Mirosława Bańki osoba dwujęzyczna to taka, która posługuje się dwoma językami (wielojęzyczna - wieloma) [Bańko, 2007, s. 417]. Według Leonarda Bloomfielda i Ewy Lipińskiej o dwu- i wielojęzyczności świadczy biegła znajomość języków, czyli zdobycie pełnej kompetencji językowej i komunikacyjnej w mowie i piśmie według tzw. kryterium kompetencji [Błasiak-Tytuła, 2011, s. 59]. Dotyczyłoby to jednak tylko tych użytkowników języka, którzy opanowali sprawności czytania i pisania. Dwu- i wielojęzyczność dzieci może być

1 Według autorów Europejskiego systemu opisu kształcenia językowego wielojęzyczność to „znajomość kilku języków przez indywidualnego człowieka lub współistnienie różnych języków używanych przez daną społeczność” [Coste, North, Sheils, Trim, 2003, s. 15], różnojęzyczność zaś to „posługiwanie się każdym ze znanych języków w celach komunikacyjnych [...] gdy dana osoba wykazuje różne stopnie sprawności w porozumiewaniu się kilkoma językami. [...] Nie oznacza to hierarchicznego współistnienia różnych oddzielnych kompetencji, lecz raczej istnienie jednej złożonej kompetencji, z której korzysta użytkownik" [Coste, North, Sheils, Trim, 2003, s. 145].

2 „Językowe kompetencje komunikacyjne to kompetencje pozwalające uczestnikowi życia społecznego działać za pomocą środków językowych”, a działanie językowe to „zastosowanie językowych kompetencji komunikacyjnych w konkretnej sferze życia do stworzenia bądź rozumienia jednego lub więcej tekstów w celu wykonania zadania" [Coste, North, Sheils, Trim, 2003, s. 20]. 
rozpatrywana jedynie przez pryzmat użycia i oznaczałaby używanie języków w życiu codziennym [Błasiak-Tytuła, 2011, s. 60].

W literaturze opisującej zagadnienia dwu- i wielojęzyczności stosuje się pochodzące z języka angielskiego (language) oznaczenia L1, L2, L3 itd. (będę je stosowała w niniejszym artykule). Odnoszą się one do kolejności nabywania języków. I tak: L1 to język pierwszy, przyswojony najwcześniej (do trzeciego roku życia) w sposób naturalny, L2 - drugi w kolejności opanowany język, L3 - trzeci itd. Tradycyjnie, biorąc pod uwagę relacje emocjonalno-kulturowe, określano je mianem język ojczysty/ macierzysty i język obcy. Ze względu na złożoność zjawiska dwujęzyczności Józef Porayski-Pomsta proponuje, by wprowadzić pojęcia język funkcjonalnie pierwszy, język funkcjonalnie drugi itd. Wynika to z faktu, że:

[...] ani kolejność przyswajania języków, ani też emocjonalny stosunek do nich nie zawsze decydują o tym, jaką rzeczywistą funkcję komunikacyjną pełnią one w określonej sytuacji komunikacyjnojęzykowej [Porayski-Pomsta, 2010, s. 331].

Potwierdzałyby to przykłady dzieci uczęszczających do Kids \& Co., których rodzice posługują się innym językiem niż używany w kraju osiedlenia (tu: językiem polskim). Dzieci te większość dnia przebywają w przedszkolu i używają w kontaktach z rówieśnikami języka polskiego (oczywiście w miarę swoich możliwości), a języka angielskiego $\mathrm{z}$ wychowawcą anglojęzycznym. Językiem funkcjonalnie pierwszym jest zatem język polski albo język angielski, a nie L1.

Ida Kurcz [2007, s. 21] dzieli dwujęzyczność dzieci na równoczesną, gdy L2 wprowadzany jest przed trzecim rokiem życia, i sukcesywną, gdy ma to miejsce później. Autorka wyodrębnia cztery strategie nauczania dzieci L2:

1) strategia osoby - gdy jedna osoba mówi do dziecka w L1, druga zaś w L2,

2) strategia miejsca - gdy L1 posługują się wszyscy domownicy, a L2 jest używany przez dziecko w szkole,

3) strategia czasu - gdy L1 towarzyszy pewnym porom dnia, a L2 innym,

4) strategia przemienna - gdy L1 naprzemiennie używa się z L2 w dłuższych okresach.

Z dwu- i wielojęzycznością dziecięcą wiążą się ściśle dwa pojęcia: submersja i immersja. Immersja to zanurzenie dziecka w L2 w sytuacji, gdy L1 ma wysoki prestiż społeczny, jest językiem cenionym przez samo dziecko. To typ dwujęzyczności wzbogacającej. Submersja natomiast to wchłonięcie, sytuacja, gdy L2 przysłania L1. Jest to dwujęzyczność zubażająca. Dochodzi do niej głównie wtedy, gdy dziecko nie osiąga pełnej kompetencji językowej w L1, może też nie zdobyć jej w L2. Dzieje się tak często w rodzinach imigrantów [Kurcz, 2007, s. 23].

Charakterystyczne dla mowy osób dwu- i wielojęzycznych są przełączanie kodów (code-switching) i interferencje językowe. Przełączanie kodów to zmiany języka $\mathrm{w}$ trakcie bezpośredniego komunikowania się z innymi. Włączanie do wypowiedzi 
w jednym języku różnych elementów językowych $z$ drugiego języka jest zgodne z normą.

Interferencje językowe to natomiast przenoszenie struktur językowych z L1 do L2. Zachodzą one na płaszczyźnie gramatycznej i leksykalno-semantycznej. Utrudniają nabywanie pełnej kompetencji językowej w L2 i zawsze są błędem. W przypadku przełączania kodów oba systemy językowe są zastosowane poprawnie, jest to często świadomy wybór osoby mówiącej.

W dwu- i wielojęzyczności małych dzieci odstępstwa od normy językowej nie są interferencją, ale rozwojowymi błędami językowymi, które popełniają tak, jak ich jednojęzyczni rówieśnicy, rozwój mowy nie został bowiem jeszcze zakończony.

\section{Podstawowe zasady budowania indywidualnego programu terapii w nauczaniu języka polskiego jako obcego}

Pierwszym etapem konstruowania indywidualnego programu terapii jest orientacyjne badanie mowy w sytuacji kierowanej zabawy, a następnie badanie rozumienia i mówienia. Choć w diagnozowaniu, które uwzględnia podejście humanistyczne, nie korzysta się z metod zamkniętych [Cieszyńska-Rożek, 2012, s. 68], z mojej praktyki wynika, że warto je zastosować. Nazywanie obrazków pozwoli na sprawdzenie i zorientowanie się w zasobie słownictwa dziecka zgodnie z etapem jego rozwoju. Badanie to przynosi również ważną informację - w jakim stopniu dziecko opanowało L1. Jest to oczywiście możliwe pod warunkiem, że terapeuta zna podstawy L1 dziecka.

Niezwykle ważnym etapem przygotowania planu pracy jest wywiad z rodzicami, ponieważ oprócz informacji na temat dwujęzycznego rozwoju dziecka konieczne jest nawiązanie kontaktu z opiekunem. W trakcie rozmowy poszukuje się odpowiedzi na pytania dotyczące języka, jakim dorośli posługują się w domu z dzieckiem, czasu pobytu w Polsce i planów związanych z pozostaniem w naszym kraju. Ostatnie pytanie jest ważne w kontekście postawy opiekunów wobec wielojęzyczności dziecka. Z mojej praktyki wynika, że młodzi rodzice traktują naukę L3 (angielskiego) zadaniowo, upatrując w nim szansy na lepszy start w dorosłość. Ma to pewne uzasadnienie, lecz uważam, że traktując naukę L3 jako projekt, zubażają L1 i lekceważą naukę L2 (tu: języka polskiego). Może to prowadzić do trudności szkolnych, ponieważ język ten będzie przecież językiem dalszej edukacji dziecka w przypadku pozostania w Polsce.

Kolejnym etapem opracowania planu terapii jest zebranie korpusu leksemów niezbędnych w codziennej komunikacji. Odpowiadają one poszczególnym kręgom tematycznym dotyczącym życia przedszkolnego i otoczenia, w którym dzieci spędzają większą część dnia. Będą to: podstawowe czynności, pożywienie, części garderoby, samopoczucie, emocje, pojęcia związane ze środowiskiem naturalnym: pory roku, pogoda, zwierzęta etc. 
Ustalenie zakresu słownictwa zakłada odtwarzanie kolejnych faz rozwoju mowy. Jest więc zgodne z podejściem rozwojowym w terapii logopedycznej. Wynika z niego, że we wszystkich językach wspólną cechą wczesnego etapu rozwoju jest nagromadzenie rzeczowników w wypowiedziach dzieci, a następnie wypowiedzi dwuelementowych (podmiot-orzeczenie, orzeczenie-dopełnienie), które umieszcza się w odpowiednich kontekstach komunikacyjnych [Nott-Bower, 2015, s. 38].

Na tym etapie terapii niezbędna jest wiedza dotycząca kolejności wprowadzania przypadków gramatycznych w języku polskim. Jako pierwszy w prowadzany jest mianownik, co wiąże się z nazywaniem, przedstawianiem się, nawiązywaniem kontaktu z innymi (To jest..., Co to jest?, Mam na imię..., Jak masz na imię?). Kolejnym przypadkiem jest biernik, którego używa się w konstrukcjach dotyczących zakupów, posiadania, próśb, ubierania (Proszę o..., Mam..., Widzę..., Podaj mi... etc.). Trzecim w kolejności wprowadzania jest narzędnik - wiąże się on z tematami o podróżowaniu, zainteresowaniach, przygotowywaniu posiłków z dodatkami oraz gdy wprowadzane są stosunki przestrzenne wyrażane za pomocą przyimków łączących się z narzędnikiem ( $\mathrm{z}$, pod, między, na - Interesuję się... - czym?, Jadę na wakacje... - czym?, Proszę pizzę z... - czym?). Następny przypadek to dopełniacz przydatny na zajęciach o zaprzeczeniach, posiadaniu, poszukiwaniu, podróży, liczeniu (Nie mam... - czego?, Szukam... - czego?, Jadę dokąd? do... - czego?). W żadnym z wymienionych przypadków nie występują nowe oboczności w temacie fleksyjnym - inne niż te, które pojawiły się w mianowniku (tu występują typowe oboczności towarzyszące przekształceniom liczby pojedynczej rzeczownika na formę liczby mnogiej np.: r : rz - lektor - lektorzy, o : ó - lód : lody, ą : ę - mąż : mężowie, e : $\varnothing$ - pies : psy, k : k' słoik : słoiki), zapamiętanie ich formy nie sprawia zatem uczniom trudności - inaczej niż w miejscowniku, który omawia się na dalszych zajęciach. W jego formach prawie zawsze występują typowe dla polszczyzny oboczności tematyczne, jednakże pojawia się bardzo często w tekstach i jest on niezbędny w komunikacji. $Z$ racji rzadkiego użycia jako ostatnie wprowadza się celownik i wołacz ${ }^{3}$.

Jeśli chodzi o czasowniki, wprowadza się takie, które odpowiadają ustalonym wcześniej kręgom tematycznym, najpierw w czasie teraźniejszym. Z mojej praktyki wynika, że stosunkowo wcześnie należy wprowadzić tryb rozkazujący. Z poleceniami dzieci spotykają się codziennie (Wstań!, Wstańcie!, Jedz!, Umyj ręce!, Usiądź!, Usiądźcie!, Spójrz!, Posłuchaj! itd.), a rozumienie i zastosowanie się do komend nauczyciela i logopedy znacznie ułatwi dziecku funkcjonowanie w grupie.

Bardzo ważną częścią każdych zajęć są ćwiczenia usprawniające narządy mowy i rozwijanie kompetencji fonologicznych, przygotowujące do innych czynności komunikacyjnych. Umiejętność rozpoznawania dźwięków (zwłaszcza rozróżnianie szeregów polskich głosek dentalizowanych) oraz ich poprawna artykulacja przyczyniają

3 Więcej o kolejności wprowadzania przypadków gramatycznych i towarzyszących im zagadnieniach gramatycznych w artykule E. Wierzbickiej-Piotrowskiej [2017]. 
się do lepszego opanowania podstawowych sprawności: słuchania, mówienia, czytania i pisania [Saran-Pasoń, 2010, s. 77]. Budowanie podsystemu fonologicznego oparte jest na różnego typu ćwiczeniach: słuchowych - rozwijających pamięć słuchową i koordynację słuchowo-wzrokową (rozpoznawanie dźwięków otoczenia, wskazywanie źródła dźwięku, wyliczanki, rymowanki), logorytmicznych - rozwijających słuch muzyczny i poczucie rytmu, wspomagających koncentrację oraz doskonalących funkcjonowanie narządów artykulacyjnych przez usprawnianie motoryki dużej (zabawy z muzyką), fonacyjnych (zabawy z samogłoskami), sprawności manualnych (wycinanie, wylepianie), rozpoznawania graficznych odpowiedników głosek, polegających na czytaniu (warta polecenia jest seria książek Anity Głowińskiej pt. Kicia Kocia) i oglądaniu bajek związanych $\mathrm{z}$ danym tematem i funkcją komunikacyjną (Świnka Peppa czy fragmenty Misia Uszatka).

Wszystkie ćwiczenia wykonywane $\mathrm{w}$ formie zabawy dostosowane są do etapu rozwoju dziecka, jego możliwości i zainteresowań. Opierają się na zasadach pracy z dzieckiem z opóźnionym lub niezakończonym rozwojem mowy. Konstruując plan pracy z dzieckiem wielojęzycznym, powinno się przede wszystkim pamiętać o tym, że każde dziecko jest inne i każde ma swoją dwujęzyczną historię. W myśl głównych założeń tzw. krakowskiej szkoły logopedii humanistycznej:

[...] chodzi bowiem o to, że badacz powinien zająć się Osobami, a nie oddzielonym od człowieka problemem. To oznacza, że osoby - dwujęzyczne dzieci i ich rodzice - są podmiotem refleksji, nie zaś sam wyabstrahowany problem posługiwania się dwoma językami [Cieszyńska, 2010, s. 10].

Pamiętając, że dwujęzyczność jest procesem, warto zadawać sobie sformułowane przez J. Cieszyńską pytania - „Co jest?”, „Dlaczego jest?”, „Co mogłoby być?” - nie tylko na początku drogi terapeutycznej, ale także w jej trakcie. Warto kierować się cechami precyzyjnej diagnozy [Młyński, 2012, s. 104]:

1) ciągłością, która polega na okresowej powtarzalności w celach weryfikacyjnych;

2) polimodalnością, która zakłada nie tylko badanie funkcji psychicznych, ale też holistyczne ujmowanie osoby;

3) użytecznością w celu skonstruowania planu terapii odpowiadającej aktualnym potrzebom i umiejętnościom dziecka.

\section{Specyfika pracy Niepublicznego Dwujęzycznego Przedszkola Kids \& Co.}

Edukacja anglojęzyczna w przedszkolu Kids \& Co. jest zgodna z założeniami podstawy programowej wychowania przedszkolnego [Rozporządzenie MEN z dnia 23 grudnia $2008 \mathrm{r}$. w sprawie podstawy programowej wychowania przedszkolnego 
oraz kształcenia ogólnego w poszczególnych typach szkół, Dz.U. Nr 4, poz. 17]. W tym programie edukacyjnym korzysta się z kanadyjskiej metody immersji, polegającej na „zanurzeniu” dzieci w języku angielskim, przy założeniu, że „około 50\% sytuacji komunikacyjnych w przedszkolu zostanie przeprowadzonych całkowicie w języku angielskim bez wspomagania się tłumaczeniem na język polski” [Kucharska, 2012, s. 6]. Dotyczy to nie tylko czasu zajęć dydaktycznych, ale także innych sytuacji komunikacyjnych (zabaw na dworze, czynności higienicznych, jedzenia etc.). Nauczyciel anglojęzyczny posługuje się wyłącznie językiem angielskim we wszystkich sytuacjach i kontaktach - również z innymi pracownikami przedszkola.

Podstawową metodą bilingwalnej edukacji, jak już wcześniej wspomniałam, jest metoda immersji, w której wykorzystuje się rozmaite techniki nauczania. Do najważniejszych należą [Kucharska, 2012, s. 13, 14]:

1) nauczanie sytuacyjne - treści nauczania odnoszą się bezpośrednio do środowiska znanego dzieciom;

2) dostosowanie materiału i treści do poziomu intelektualnego dzieci, mówienie prostym, ale nie uproszczonym językiem;

3) rezygnacja z poprawiania na rzecz powtórzenia za dzieckiem poprawnej formy;

4) prawo do ciszy (silent period) - czas, w którym dziecko oswaja się z językiem obcym i nie musi go używać;

5) większe wymagania dotyczące rozumienia języka angielskiego niż budowania słownych komunikatów;

6) dostarczanie zróżnicowanych materiałów wizualnych i słuchowych.

\section{Wielojęzyczne dzieci}

Dla większości dzieci uczęszczających do przedszkola Kids \& Co. język polski jest L1, język angielski L2 - z racji dwujęzycznego charakteru kształcenia. Część dzieci pochodzi z rodzin imigrantów, zaczynają one edukację jeszcze przed ukończeniem trzeciego roku życia, oprócz przyswajania L1 muszą zatem przyswoić L2 (język polski) i L3 (angielski). Sytuacja tych dzieci jest skomplikowana i rodzi wiele trudności. Z mojego doświadczenia wynika, że przynajmniej w pierwszym roku nauki postrzegane są przez wychowawców i personel jako „trudne”. Często nie angażują się w działania grupy, bawią się same, bywają zalęknione i wycofane. Nie mogąc porozumieć się z rówieśnikami, odsuwają się od nich. Problemy w komunikacji utrudniają proces wychowania, izolacja zaś (mimo dobrej woli i starań opiekunów) prowadzi czasami u nich do zachowań agresywnych.

Niebagatelną rolę ma też poczucie tożsamości wielojęzycznych dzieci, którą buduje wspólnota językowa. Trudności językowe są bezpośrednią przyczyną niepowodzeń w komunikacji z innymi oraz zaburzają rozwój indywidualny i społeczny tych dzieci. 
Jak już wspomniałam, dzieci z rodzin imigrantów zaczynają edukację w Polsce bardzo wcześnie, kiedy ich rozwój mowy i nabywanie L1 nie zostały zakończone. Dlatego też przyswajanie L2 jako języka osiedlenia powinno być wspomagane nauczaniem formalnym, którego podstawowym celem jest wykształcenie kompetencji komunikacyjnej zgodnej z wiekiem umysłowym dziecka. Należy mieć również na względzie to, że większość dzieci imigrantów kontynuuje naukę w Polsce. Aby zapobiec trudnościom szkolnym, poczuciu wykluczenia i problemom w budowaniu tożsamości wynikającym z zaburzeń komunikacji językowej, należy zatem jak najszybciej objąć dzieci wielojęzyczne opieką specjalisty w zakresie nauczania języka polskiego jako obcego.

W przedszkolu Kids \& Co. część dzieci uczestniczy w zajęciach logopedycznych. O udziale w nich decyduje przyjęta przeze mnie definicja języka według Andrzeja Markowskiego i Jagody Cieszyńskiej-Rożek. Według Markowskiego:

[...] język jest podstawowym narzędziem ludzkiego myślenia. [...] Uzewnętrznieniem procesu myślenia jest formułowanie tekstów językowych, opartych na znajomości systemu językowego. [...] Jest pośrednikiem w kontaktach międzyludzkich - od tych najbardziej intymnych, poprzez codzienne, prywatne, oficjalne [...] [Markowski, 2009, s. 9-10].

Jagoda Cieszyńska-Rożek dostrzega, że język jest „aktem wzajemnego zrozumienia, a poprzez nie doświadczania świata drugiej osoby" [Cieszyńska-Rożek, 2012, s. 73]. Jeśli w procesie komunikacji dochodzi do zakłóceń, należy temu skutecznie przeciwdziałać i zapobiegać pogłębianiu się problemów. Dlatego też na zajęcia logopedyczne kwalifikowane są dzieci wielojęzyczne, które mają utrudniony kontakt z innymi ludźmi, spowodowany nieznajomością języka polskiego, oraz te, które mają jakiekolwiek zaburzenia artykulacyjne i fonacyjne i/lub niezakończony rozwój mowy.

Dzieci dwu- i wielojęzyczne, z którymi pracuję jako logopedka, zaczęły uczęszczać do żłobka lub przedszkola przed ukończeniem trzeciego roku życia. Jest to zatem przykład dwu- i wielojęzyczności równoczesnej. Inaczej sprawa przedstawia się, gdy chodzi o strategie nauczania oraz wpływ dwujęzyczności na rozwój kompetencji językowej w L1 i L2. Poniższe przykłady zilustrują ten problem.

Diana (lat 4,5) w Polsce przebywa od 2015 roku, od tego roku uczęszcza do przedszkola Kids \& Co. W momencie rozpoczęcia edukacji miała rok i 8 miesięcy. Rodzice mówią do dziecka w języku ukraińskim. Jest to dla dziewczynki Ll. W przedszkolu styka się z językiem polskim i angielskim. Ponieważ język polski jest bliski genetycznie i kulturowo językowi ukraińskiemu, będzie on L2, a język angielski L3 - z racji przynależności do innej rodziny języków ${ }^{4}$. W przypadku Diany zachowane

4 Złożoność tego zjawiska omawia w swoim artykule Dwujęzyczność dziecięca w perspektywie glottodydaktyki i logopedii Rafał Młyński [2012, s. 106]. 
są strategie nauczania: osoby (L1 - rodzice, L2 - rówieśnicy, logopeda i wychowawca polskojęzyczny, L3 - nauczyciel anglojęzyczny), miejsca (L1 - dom, L2, L3 - przedszkole) i czasu (L1 - poranek i późne godziny popołudniowe, L2, L3 - czas przebywania w przedszkolu). Dla rodziców Diany L1 ma wysoki prestiż i jest ceniony przez samą dziewczynkę. L1 nie został wchłonięty przez L2 ani przez L3, choć dziewczynka uczęszcza do przedszkola 3 lata. To przykład wielojęzyczności wzbogacającej. Dziecko posługuje się wprawdzie często językiem ukraińskim w kontaktach z rówieśnikami i nauczycielami polskojęzycznymi, ale podejmuje próby wypowiadania się w języku polskim albo angielskim, gdy rozmawia z nauczycielem angielskojęzycznym.

W języku angielskim Diana rozumie proste polecenia i krótkie teksty mówione, bezbłędnie nazywa kolory i powtarza za nauczycielem słowa, ale z trudnością wypowiada się samodzielnie. Lepiej radzi sobie z posługiwaniem się językiem polskim (z racji jego pokrewieństwa $\mathrm{z}$ językiem ukraińskim). W czasie pierwszego spotkania Diana wszystkie ilustracje $\mathrm{z}$ kwestionariusza badania mowy nazwała po ukraińsku. Po dwóch latach nauki języka polskiego rozumie polecenia, potrafi zadać proste pytanie, nazywa dużą część obrazków po polsku.

Dziewczynka ma niską sprawność narządów artykulacyjnych, dlatego na każdych zajęciach wykonuje ćwiczenia usprawniające motorykę warg i języka.

W wypowiedziach Diany pojawiają się charakterystyczne dla wielojęzyczności przełączanie kodów (Jа хочу powiedzieć, Ја люблю pomidory i ziemniaki), hybrydy (apusz -ang. apple + pol. jabłuszko, dak - ros. да + pol. tak), interferencje językowe (Papa mój, mama mój i ja. Dwa lampy. Moja imię piesek Misia. Tu jest oczy, tu jest uszy. „[logopeda:] On mieszka z tobą? - [pacjent:] Tak, z tobą, w domu”, „[logopeda:] Dlaczego jesteś zmęczona? - [pacjent:] Jak biegać.”).

Diana z trudnością przyswaja sobie nowe leksemy, dopiero po kilkakrotnym ich powtórzeniu potrafi je odtworzyć. Wprawdzie wolniej uczy się nowych rzeczy, ale opanowała dobrze L1 i w nim rozwinęła swój potencjał językowy.

Iryna (lat 3,5) przyjechała do Polski w 2017 roku. Do przedszkola uczęszcza od kwietnia tegoż roku. Miała wtedy 2 lata i 5 miesięcy. Do drugiego roku życia przebywała wśród osób mówiących po rosyjsku - jest to więc L1 dziecka. Matka dziewczynki zna biegle język angielski i w stopniu bardzo dobrym język włoski, oba mają dla niej wysoki prestiż, dlatego często zwraca się do córki w tych językach (częściej po angielsku). W przedszkolu Iryna styka się z językiem polskim i angielskim. Dla dziewczynki L1 jest język rosyjski z racji czasu, w którym następowało jego przyswojenie, ale inaczej niż u Diany, L2 to język angielski, a L3 polski. W tym przypadku trudno o zachowanie strategii osoby, miejsca i czasu. Matka, dla której L1 to rosyjski, nie zawsze zwraca się w nim do dziecka, dlatego L1 Iryny został w części wchłonięty przez L2. To przykład dwujęzyczności zubażającej, L2 przysłania L1. W przypadku Iryny L2, czyli angielski, przysłania L1 - język rosyjski. W przedszkolu, w którym dziewczynka spędza codziennie około 9 godzin, używa L2, rzadko posługuje się L1 - nawet w kontaktach z innymi dziećmi, dla których L1 to również język rosyjski lub 
ukraiński, natomiast w L3 mówi na zajęciach logopedycznych i czasami w kontakcie z rówieśnikami polskojęzycznymi.

Podczas pierwszego spotkania Iryna część obrazków z kwestionariusza mowy nazwała po angielsku, kilka po rosyjsku, dwa wyrazy po włosku (wł. cane, gelato).

Spontaniczne wypowiedzi Iryny są niezrozumiałe. Nie jest to spowodowane warunkami anatomiczno-czynnościowymi dziewczynki, jej sprawność artykulacyjna mieści się w normie. Dziecko wyraźnie mówi pojedyncze wyrazy i proste, dwuwyrazowe zdania w języku angielskim. Reszta jej wypowiedzi to niezrozumiały zlepek słów brzmiących podobnie do wyrazów angielskich. Iryna, naśladując melodię tego języka, tworzy neologizmy (najczęściej są to wyrazy z charakterystyczną dla języka angielskiego głoską r). Świadczy to z pewnością o niezwykłej pomysłowości dziecka i dobrym słuchu, ale znacząco utrudnia jej porozumienie się z innymi.

W wypowiedziach dziewczynki pojawiają się bardzo często przełączanie kodów - There are prostokąty. Eta śnieg. Krasny i biały dom. Qui, here, tutaj (zamiennie używane przy wskazywaniu), Ciocik (ciocia) talk about..., Tutaj is castle, Tutaj jest brother, Tutaj is reading book, Tutaj is kolorowana, Prezent for Irynki, Ja byłam na plażu - i interferencje językowe -To moje zjedzenie!, Jak mi. (Jak ja), Do kątu ją włożyła, Tu mój zeszyt domu.

Iryna bardzo szybko zapamiętuje nowe leksemy, nie ma problemów z nabywaniem i nauką języka polskiego i angielskiego. Niestety, najprawdopodobniej nie osiągnie pełnej kompetencji językowej ani w L1, gdyż został on przysłonięty przez L2 (język angielski), ani w L2, gdyż proces jego nabywania rozpoczął się w momencie niezakończonego kształtowania się L1.

\section{Podsumowanie}

Ważnym elementem w procesie nabywania języka jest jego formalne nauczanie. Jest ono nieodzowne w przypadku dzieci wielojęzycznych, które będą kontynuowały edukację w Polsce. Nauczanie języka polskiego jako obcego wspomaga jego przyswajanie i pozwala stosunkowo szybko zaadaptować się dziecku w nowym środowisku.

Bardzo ważna jest tu współpraca logopedy/lektora $\mathrm{z}$ rodzicami. Od ich postawy wobec wielojęzyczności dziecka wiele zależy. Budowanie przez opiekunów wysokiego prestiżu L1 jest konieczne w kształtowaniu się tożsamości dziecka, we wzmacnianiu jego poczucia przynależności do danej wspólnoty językowej oraz poczucia własnej wartości. Taka postawa pomaga w rozwijaniu funkcji poznawczych dziecka, w jego rozwoju intelektualnym i językowym.

Trudności, z jakimi spotykają się dzieci dwu- lub wielojęzyczne, są nieuniknione, dlatego należy wspomagać je w wielojęzycznym rozwoju. Korzystając z osiągnięć glottodydaktyki polonistycznej i logopedii oraz opierając się na ich praktycznych podstawach, można opracować skuteczny plan pracy z pacjentem. Najważniejszą 
bowiem rzeczą jest usprawnienie kompetencji językowych i komunikacyjnych tak, aby nie tracąc swojego L1, dziecko mogło swobodnie porozumiewać się z otoczeniem, w którym przyszło żyć całej rodzinie i nie czuć się wykluczonym ze środowiska rówieśniczego.

Literatura

Bańko Mirosław (red.), 2007, Słownik języka polskiego, t. 1, Warszawa: Wydawnictwo Naukowe PWN.

Błasiak-Tytuła Marzena, 2011, Kilka uwag na temat bilingwizmu, [w:] M. Michalik (red.), Nowa logopedia, t. 2: Biologiczne uwarunkowania rozwoju i zaburzeń mowy, Kraków: Collegium Columbinum, s. 57-70.

Cieszyńska Jagoda, 2010, Dwujęzyczność - rozumienie siebie jako Innego, [w:] J. Cieszyńska, Z. Orłowska-Popek, M. Koredo (red.), Nowe podejście w diagnozie i terapii logopedycznej - metoda krakowska, Kraków: Wydawnictwo Naukowe Uniwersytetu Pedagogicznego, s. 1-22.

Cieszyńska-Rożek Jagoda, 2012, Rozwój mowy polskich dzieci na obczyźnie - zjawiska normatywne czy zaburzenia rozwojowe?, [w:] M. Michalik, A. Siudak, Z. Orłowska-Popek (red.), Nowa logopedia, t. 3: Diagnoza różnicowa zaburzeń komunikacji językowej, Kraków: Collegium Columbinum, s. 67-83.

Coste Daniel, North Brian, Sheils Joseph, Trim John, 2003, Europejski system opisu ksztatcenia językowego: uczenie się, nauczanie, ocenianie, Warszawa: Wydawnictwa Centralnego Ośrodka Kształcenia Nauczycieli.

Kucharska Angelika, 2012, Dwujęzyczny świat dzieci. Program edukacji anglojęzycznej dla dzieci $w$ wieku przedszkolnym, dokument wewnętrzny Kids \& Co., Warszawa.

Kurcz Ida, 2007, Jakie problemy psychologiczne może rodzić dwujęzyczność?, [w:] taż (red.), Psychologiczne aspekty dwujęzyczności, Warszawa: Gdańskie Wydawnictwo Psychologiczne, s. 9-39.

Markowski Andrzej, 2009, Kultura języka polskiego. Teoria. Zagadnienia leksykalne, Warszawa: Wydawnictwo Naukowe PWN.

Młyński Rafał, 2012, Dwujęzyczność dziecięca w perspektywie glottodydaktyki i logopedii. Próba syntezy, [w:] M. Michalik, A. Siudak, Z. Orłowska-Popek (red.), Nowa logopedia, t. 3: Diagnoza różnicowa zaburzeń komunikacji językowej, Kraków: Collegium Columbinum, s. 93-110.

Nott-Bower Aneta, 2015, Diagnoza oraz terapia zaburzeń mowy i języka u osób dwujęzycznych, „Forum Logopedyczne”, nr 23, s. 34-40.

Porayski-Pomsta Józef, 2010, Psycholingwistyczne aspekty uczenia się vs. nauczania języka drugiego, [w:] E. Bem-Wiśniewska (red.), Zabawy pożyteczne prozą, Warszawa: Wydział Polonistyki Uniwersytetu Warszawskiego, s. 326-336.

Saran-Pasoń Edyta, 2010, Kształtowanie się systemu fonetyczno-fonologicznego u dzieci jednoi dwujęzycznych w wieku od 3. do 5. roku życia, [w:] M. Michalik, A. Siudak (red.), Nowa logopedia, t. 1: Zagadnienia mowy i myślenia, Kraków: Collegium Collumbinum, s. 71-84.

Wierzbicka-Piotrowska Elżbieta, 2017, Kolejność wprowadzania przypadków gramatycznych w nauczaniu języka polskiego jako obcego, „Kwartalnik Polonicum”, nr 26, s. 3-12. 
Streszczenie

Autorka omawia najważniejsze zagadnienia dotyczące dwu- i wielojęzyczności. Przedstawia specyfikę pracy Niepublicznego Dwujęzycznego Przedszkola Kids \& Co., oferującego model edukacji dwujęzycznej. Nadrzędnym jej celem jest osiągnięcie przez dziecko dwujęzyczności funkcjonalnej oraz przygotowanie go do kontynuacji nauki w L2. Autorka opisuje problemy językowe dzieci wielojęzycznych, które utrudniają pełne porozumienie z innymi oraz ich aspekt psychologiczny. Korzystając z własnych doświadczeń, przedstawia metody pracy z dziećmi wielojęzycznymi z punktu widzenia logopedy praktyka i lektora języka polskiego jako obcego. Podkreśla, że wspomaganie akwizycji L2 musi być oparte na nauczaniu formalnym języka. Zwraca uwagę na potrzebę wspierania dzieci w ich wielojęzycznym rozwoju.

\section{Summary}

The author describes the most important aspects of bilingualism and multilingualism by presenting the specifics of the work of Niepubliczne Dwujęzyczne Przedszkole KIDS \& Co. which offers bilingual education. The main objective of this way of teaching is to achieve a functional bilingualism among children and to prepare them for further learning processes conducted in the second language. The author characterizes both, multilingual children's language difficulties, which may hinder communication with others, and the psychological aspects of a sense of alienation and disability to be a community member. Using her work experieince, the author presents the methods of working with multilingual children, from a speech therapist's, and a Polish language as L2 teacher's, point of view. The author emphasizes the importance of supporting the children's speech with a formal way of teaching Polish, and points out the need to assist them in their multilingual growth. 